\title{
REMARKS ON THE POSITION, THE DELIMITATION AND THE SUBDIVISION OF THE RUBIAGEAE
}

\author{
C. E. B. BREMEKAMP \\ (Botanical Museum and Herbarium, Utrecht)
}

(received October 22nd, 1965)

\section{INTRODUCTION}

It is often assumed that the delimitation and the subdivision of the various families which have been distinguished in the Angiosperms, do no longer offer serious difficulties. They would belong to those objects of study for which already long ago a fairly satisfactory solution was found. If we wish to be acquainted with this solution, the only thing we would have to do, would be to look up such works as Bentham and Hooker's "Genera Plantarum" and Engler and Prantl's "Natürliche Pflanzenfamilien". Some improvements might still be desirable, but these would be of minor importance only. These assumptions, however, are to be regarded as dangerous illusions.

That the very serious nature of the shortcomings found in the delimitation and subdivision of these families, especially of the larger ones, is so often overlooked, is apparently due to an attitude of mind which is observed in a comparatively large part of the taxonomists, viz. a lack of interest in the development of a truly natural classification. This is not incomprehensible. Most of them spend the major part of their time in the elaboration of floras covering areas of more or less limited extent, and they are but rarely aware of the fact that the knowledge of the families which is obtained in this way, remains necessarily incomplete. Moreover, in the elaboration of a flora the most essential point is the construction of serviceable keys to the species as well as to the groups of higher rank, not the exact delimitation of these groups: to the latter end usually more material is required than the compiler of a flora has at his disposition. However, we must not overlook the fact that a key, in order to be serviceable, need not reflect the degree of affinity between the units with which it is dealing; in reality, such keys are often entirely or almost entirely artificial, and this applies therefore also to classifications which are based on such keys. To illustrate this, I will discuss here some of the characters by the aid of which in the Rubiaceae very suitable keys to the genera have been constructed, but which when they subsequently were used for the elaboration of a classification, led to entirely unsatisfactory results.

To the characters which for a long time have played an important part in the subdivision of the Rubiaceae, belong the presence either of uni- or of pluriovular ovary cells, their kind of fruits, which to 
this end were divided in dry and fleshy ones, and the nature of their seeds, of which also two kinds were distinguished, viz. winged and wingless ones. However, even a superficial study of the groups that have been distinguished by the aid of these characters, will show that most of them are entirely unnatural. As the differences are morphologically of hardly any value, this might have been expected.

The number of ovules per ovary cell shows a continuous range of variation, and so long as there is no reason to assume a correlation between a definite number of ovules and one or more other characters, it is therefore not justified to attach to the presence of one or two ovules per ovary cell a greater taxonomic value than to that of three or of another number of them; we know, in fact, that the number of ovules per ovary cell may vary within the limits of a single genus (see my "Monograph of the genus Pavetta L" in Fedde, Repertorium 37: 10. 1943, and my remarks on the genus Anotis DC and the Cruckshanksieae in the last chapter of the present publication) as well as in genera that on account of their many common features are to be regarded as nearly related, so e.g. in Tarenna Gaertn. and Pavetta L (see p. 7 of my "Monograph of the genus Pavetta L").

That the difference between dry fruits and fleshy ones can not be used for the characterization of natural groups is also easily comprehensible. This distinction is an ecological, not a morphological one, and in both kinds of fruits quite considerable morphological differences are found; in some instances the differences between a dry and a fleshy fruit may even be smaller than those between two kinds of dry fruits or two kinds of fleshy ones. In the genus Mussaenda $\mathrm{L}$ species with dry fruits are found side by side with species producing fleshy ones; even if these species are divided over two genera, as sometimes is done, this does not make much difference, for in that case we will have to admit that the two kinds of fruits are found in very nearly related genera.

The same applies to the distinction between winged and wingless seeds: this too is an ecological, not a morphological distinction. From the morphological point of view these wings are by no means all alike; in the Cinchoneae, the tribe in which the genera with winged seeds were brought together, they are in the genera which may rightly be regarded as near allies of Cinchona $\mathrm{L}$, in position as well as in the structure of the cells of which they are mainly composed, entirely different from those that are found in the genera which were transferred by me to the Rubioideae.

Another drawback of the classifications accepted in the works mentioned above, is that they are based mainly on earlier classifications which were drawn up when a much smaller number of genera were known, and that the authors often assumed that the subfamilies and even the tribes based on this more limited number would suffice for the incorporation of the subsequently discovered genera. This apparently is the explanation of the fact that so often a genus has been squeezed into a tribe into which it does not fit. In the case of the Rubiaceae there are even quite a number of genera of which it is 
extremely doubtful whether they really belong to this family. This point will be discussed in the second chapter.

Many taxonomists, moreover, seem to feel a certain reluctance to accept subfamilies which contain but a single tribe, and tribes which contain but a single genus. This reluctance, however, is entirely unjustified. We know several families and even some orders which contain but a single or a very small number of genera, and there is accordingly no reason whatever for assuming that a subfamily or a tribe should always contain more than one group of the next lower rank. Whether a taxon is to be classified as a subfamily or a tribe evidently depends upon the number and the importance of the characters in which it differs from its nearest allies and on nothing else, and where our predecessors have overlooked the presence of some differences or undervalued their importance, it is doubtless our duty to correct them.

With regard to what has been said in the preceding paragraph, it is, of course, of importance to find ways and means for estimating the taxonomic value of the groups of characters that are to be used for the distinction of the tribes and subfamilies and, naturally, of the families too. In the case of the latter the number of diagnostic characters is often extremely small and their value not rarely dubious. With regard to the Rubiaceae this point will be dealt with in the chapters one and two, but at this point it is perhaps worth while to draw the attention to the fact that in the description of this family given in the works mentioned above we do not find a single character that can be regarded as a truly general one. This is, of course, due to the fact that this family, in the delimitation accepted in these works, comprises elements which do not really belong to it. The inclusion of such elements, moreover, has often led to entirely false conclusions with regard to the affinity of the families. In the case of the Rubiaceae, for instance, the inclusion of the genera Henriquezia Spruce ex Bth. and Platycarpum Humb. et Bonpl. has led to the assumption that there should be a comparatively close affinity between this family and the Bignoniaceae. However, when these two genera are excluded, it appears that not a single argument is left which might possibly be adduced in favour of this view. After the exclusion of the genera Carlemannia Bth. and Sylvianthus Hook. f. the affinity with the Caprifoliaceae and their allies has become less pronounced, and if the genus Dialypetalanthus Kuhlm. had been left in the Rubiaceae, this would have been a good argument for assuming a rather close affinity with the Myrtales! It is therefore of great importance that such misclassifications are corrected. Several other examples of genera which were incorporated in the Rubiaceae on insufficients ground, will be given in the chapter dealing with the delimitation of the family.

It can, of course, not be denied that the number of characters which related taxa have in common, decreases with the increase in rank of the taxon to which they belong; it is certainly no wonder that families have, as a rule, but a very small number of general characters. However, groups based on a single general character should always be regarded with some distrust. 
Verdcourt (Bull. Jard. bot. de l'État, Bruxelles 28: 228. 1958) discusses my subfamily Ixoroideae and rejects it because the pollination mechanism which is a general feature of this group, is thought to be present also in some genera which belong to other circles of affinity, a point that will be discussed in chapter three, and further because this pollination mechanism is regarded by him as a single character. This is certainly not so. The type of pollination mechanism which is characteristic for the Ixoroideae requires that the anthers are in the bud in contact with the part of the style which serves as a temporary depository for the pollen grains; this means that they must be found at the same height as the latter and that they open introrsely. The part of the style which serves as "receptaculum pollinis" must be covered with short hairs, otherwise it would be unable to fulfil its function. Finally the flowers must be protandrous. This type of pollination mechanism is therefore a much more complex arrangement and accordingly of much greater taxonomic importance than most other pollination mechanisms, e.g. than the heterostylism to which Verdcourt himself attaches a relatively high value. As I have discussed some time ago the relatively small taxonomic value of this kind of pollination mechanism in my paper "On pollen dimorphism in heterostylous Psychotrieae, especially in the genus Mapouria Aubl." (Grana palynologica 4: 54 and 55, 1963) it seems superfluous to enter into details. Suffice it to state that heterostylism is found in several but distantly related families, that it is always restricted to part of the genera and that it is even in these genera but rarely a general feature. With the kind of pollination mechanism found in my subfamily Ixoroideae this is quite different. It is apparently restricted to this subfamily of the Rubiaceae and to a few other families, viz. the Campanulaceae, the Goodeniaceae and the Compositae, and in the two last-mentioned families the mechanism is not even quite the same, for the hairs on the style have here a different function; moreover, the receptaculum pollinis of the Goodeniaceae (the "Pollenbecher" of Schönland) occupies a different position and shows a different structure, whereas in the Compositae the receptaculum pollinis is lacking. In contradistinction with heterostylism this kind of pollination mechanism and its variations are in all the groups in which they occur, a fully general feature. The combination of characters on which it rests, is therefore to be regarded as taxonomically highly important.

My subfamily Rubioideae was accepted by Verdcourt l.c. as a natural one, although the tribes which at that moment were united in this group, had but one character in common, viz. the presence of raphides. I may add here that one of the two other subfamilies recognized by Verdcourt, viz. the Cinchonoideae, has in the delimitation accepted by him not a single general character, for the absence of raphides can certainly not be regarded as such; this would be possible only if it could be proved that they possess some mechanism which prevents the development of this kind of crytals, and that this mechanism moreover, is the same in all the tribes that have been included in this subfamily. 
That the presence of raphides is to be regarded as a taxonomically very important feature, follows from the fact that it is in the tribes in which it occurs, a general character, whereas this kind of crystals is completely absent in the other tribes of the Rubiaceae and also in all the families which are to be regarded as their nearest allies. In itself, however, their presence is not sufficient to prove that the affinity of the tribes in which they occur, is so close that they are to be united in a single subfamily. In this connection it is noteworthy that most of these tribes agree also in another character, viz. in the valvate aestivation of the corolla lobes. There are, however, two tribes in which another kind of aestivation of the corolla lobes is found, viz. the Hamelieae, where the aestivation is imbricate, and the Hillieae, where it is contorted. The inclusion of the Hamelieae in the Rubioideae is perhaps permitted, as at least in one of the tribes in which the aestivation is said to be valvate, viz. the Psychotrieae, at least two genera are included, viz. Notopleura Brem. and Naletonia Brem., in which the aestivation is imbricate. These two genera, of which the first was regarded by Hooker as a section of $P_{\text {sychotria }} \mathrm{L}$, are in all other respects normal members of the tribe Psychotrieae (see my "Notes on the Rubiaceae of Surinam" in Rec. d. trav. bot. Néerl. 31: 284 and 289. 1934). The case of the Hillieae, however, is an entirely different one. The inclusion of the genus Hillia Jacq. in the Cinchoneae was made possible by Hooker by means of a slight change in the definition of the latter; according to him the seeds of the Cinchoneae would be "alate or appendiculate", but the word "appendiculate" has obviously been added with the sole purpose of legitimizing the inclusion of this genus, but this can not be regarded as an acceptable solution of the difficulty caused by the neccessity of finding a place for this aberrant genus, for the tuft of hairs at the top of the seed can certainly not be homologized with a wing. That the wings with which the seeds in the other genera which by Hooker, and at an earlier date already by de Candolle, were included in this tribe, would prove to be of different kinds, could not be foreseen at that time, but this excuse can not be brought forward in the case of the genus Hillia, as the latter does not show the slightest resemblance to any of the genera with winged seeds that rightly or wrongly were brought together in this tribe. Schumann makes it even worse, for notwithstanding the fact that according to his definition of the Chinchoneae the seeds are always winged, he too includes the genus Hillia in this tribe. Hillia, however, occupies a very isolated position in the family. One of its most remarkable features is found in the structure of the testa cells, which show a rather striking resemblance with those of the genus Gleasonia Standl., another genus occupying a rather isolated position; in their other characters, however, these two genera show no resemblance whatever. Hillia as well as Gleasonia are therefore referred by me to subfamilies of their own.

\section{The position of the Rublaceae}

In order to determine the taxonomic value of the various cha- 
racters that are met with in a family, it is desirable to know something of the distribution of these characters in the families which are to be regarded as its nearest allies. With this end in view we will consider briefly the position which is to be assigned to the Rubiaceae in the system of the Angiosperms. In more recent times this problem has been discussed at some length by UTzschneider (Mitt. Bot. Staatssamml. München 3: 96-98. 1951) and by Wagenitz (Bot. Jahrb. 79: 17-35. 1959).

Wagenitz comes to the conclusion that the order of the Rubiales as defined in Engler's "Syllabus", i.e. as a group comprising the Rubiaceae, Caprifoliaceae, Adoxaceae, Valerianaceae and Dipsaceae, can not be regarded as a natural one, because the points of resemblance between the Rubiaceae and the other families included in this group appear to be of less importance than those between the Rubiaceae and some of the families that were included in the order which at that time was known as the Contortae. These points of resemblance become even more striking if this order is given a more natural delimitation by removing the Oleaceae to an order of its own, the Oleales, and the Buddleiaceae to the order formerly known as the Tubiflorae, where it may be put in the vicinity of the Scrophulariaceae, a family in which some of its representatives formerly had been included, e.g. by de Jussieu. On account of the many points of resemblance which the Rubiaceae show with the Loganiaceae and their nearest allies, they are included by Wagenitz in this group of families, for which he introduces the name Gentianales Lindley emend. Wagenitz. This order, therefore, comprises in his delimitation the families Loganiaceae, from which the Buddleioideae are excluded, Rubiaceae, Apocynaceae, Asclepiadaceae, Gentianaceae and the rather aberrant Menyanthaceae. The other families of the former Rubiales are kept together in an order for which he uses the name Dipsacales Lindley emend. Nakai.

The points in which the Rubiaceae resemble the other families of the Gentianales sensu Wagenitz and those in which they differ from the Dipsacales sensu Nakai may be summarized as follows. The leaves of the Gentianales are, except in the Menyanthaceae, decussate or, more rarely, verticillate, those of the Dipsacales either decussate or alternate; in the Gentianales they are, moreover, simple and entire, though here too an exception to this rule is found in the Menyanthaceae, whereas in the Dipsacales they are either simple or, more rarely, pinnately compound and often dentate or more deeply incised. The corolla is in the Gentianales always actinomorphic, and in the Dipsacales either actinomorphic or, more often, more or less distinctly zygomorphic. The androecium is in the Gentianales always isomerous, in the Dipsacales either isomerous or oligomerous. The endosperm is, as far as can be judged at present, in the Gentianales always nuclear, in the Dipsacales always cellular. The stipules are in the Gentianales often provided with colleters, whereas these appendages of the stipules are in the Dipsacales always absent. True glandular hairs are, on the other hand, but rarely met with in the Gentianales, whereas they are of common occurrence in the Dipsacales. Another point of similarity 
between the Rubiaceae and the other families of the Gentianales may perhaps be seen in the presence of alcaloids; in the Dipsacales these substances are absent or at least very rare. Alcaloids belonging to the group of the tryptophans seem to be confined to the Loganiaceae, the Apocynaceae and the Rubiaceae. However, as they are not found in all the genera belonging to these families, their presence would only be of importance to the taxonomist if it could be proved that they are derived from precursors which are generally present in the Gentianales and absent in the Dipsacales. So far the most important points of resemblance between the Rubiaceae and the other families of the Gentianales seem to be the presence of colleters and the nuclear endosperm, the most important difference the absence of intraxylary phloem in the Rubiaceae and its presence in the other families, and the position of the ovary, which in the Rubiaceae is inferior or at least more or less so, and in the Gentianales always superior. In these two points the Rubiaceae agree with the Dipsacales.

The taxonomic importance of the inferior ovary, however, should not be overrated. In the great majority of the Rubiaceae the ovary is indeed completely inferior, but in the Gaertnereae, a tribe of the Rubioideae nearly related to the Psychotrieae, the ovary, though at first still partly inferior, becomes in the later stages of its development almost completely superior, and in some genera belonging to other tribes the proportion between the part of the ovary which rises above the place of insertion of calyx and corolla and that below the latter, may vary considerably. In the genus Mitrasacmopsis Jovet, which by its author was included in the Loganiaceae-Spigelieae, the ovary is, as in the Gaertnereae, almost completely superior; the presence of raphides proves that this genus can not belong to the Loganiaceae, a family in which raphides are entirely unknown, but that it is to be transferred to the Hedyotideae, a tribe of the Rubioideae; it is, in fact, a near ally of my genus Diotocranus, in which the ovary is also almost completely superior; the two genera even may prove to be identical.

Another point which deserves our attention when we wish to estimate the taxonomic value of the inferior ovary, is that ovaries of this kind are found in widely different families, and that in some of these families, e.g. in the otherwise rather uniform Gesneriaceae, superior as well as inferior ovaries are met with. The example of the Gesneriaceae is the more instructive as this family belongs to the Tubiflorae, an order in which all the other families are provided with superior ovaries.

The considerations expounded in the two preceding paragraphs lead to the conclusion that in the Rubiaceae the presence of an inferior ovary can be regarded only with some reserve as a general character, and that this character, moreover, is not of so paramount importance that it would in itself be sufficient to exclude this family from the Gentianales and to compel us to regard it as more nearly related to the Dipsacales.

The absence of an intraxylary phloem in the Rubiaceae forms doubtless a more serious obstacle against the inclusion of this family in the Gentianales, as this is a character which is less irregularly distributed. 
Considered in connection with the admittedly less important inferior ovary it would perhaps justify the creation of a monotypic order Rubiales. The latter would, however, be more closely related to the families which would be left in the Gentianales than to the Caprifoliaceae and the other families of the Dipsacales.

Apart from the affinity with the Gentianales and the Dipsacales that with the Campanulales should also be considered. In this connection the resemblance between the pollination mechanism of the Ixoroideae and that found in the Campanulaceae, the Goodeniaceae and the Compositae, which was discussed in the introduction, would perhaps deserve more attention than it has received so far.

\section{The Delimitation of the Rubiaceae}

In the introduction to this paper we have already pointed out that the genus Dialypetalanthus Kuhlm. had to be excluded from the Rubiaceae because it shows in the structure of the flowers with their polymerous androecium an unmistakable affinity with the families brought together in the Myrtales. We might have added that nowhere else in the Rubiaceae any indications of an affinity with this order is to be found (cf. Rizini et Occhioni in Lilloa 17: 253. 1949). For a similar reason Henriquezia Spruce ex Bth. and Platycarpum Humb. et Bonpl. had to be excluded. These two genera show in the slightly zygomorphic corolla and in the quite distinctly zygomorphic androecium and also in the large exalbuminous seeds a high degree of similarity with the Bignoniaceae and some other families of the Tubiflorae, whereas elsewhere in the Rubiaceae, if we except a few other anomalous genera which, as I will show hereafter, have been included on insufficient grounds, no indications of such a relationship can be detected (see my paper "On the position of Platycarpum Humb. et Bonpl., Henriquezia Spruce ex Bth. and Gleasonia Standl. in Acta Bot. Neerl. 6: 351 377. 1957). The genera Carlemannia Bth. and Sylvianthus Hook. f. were excluded already at a much earlier date by Solereder (Bull. Herb. Boiss. 1: 173-178. 1893). On account of the dentate or serrate leaves, the rudimentary stipules and the oligomerous androecium they are to be removed to a position in the vicinity of the Caprifoliaceae, i.e. to the Dipsacales (see my note on these genera in Rec. d. trav. bot. néerl. 36: 372. 1939).

The genera mentioned above are not the only ones that will have to be excluded, whereas the position of some other genera is extremely doubtful and should be reconsidered.

The genus Opercularia Gaertn., now usually included in the Anthospermeae, was on account of its unilocular ovary and the oligomerous androecium referred by DE Jussieu (Ann. Mus. d'Hist. Nat. 4: 118. 1824) to a family of its own, the Operculariaceae, but Richard (Mém. sur la famille des Rubiacées: 62-67. 1830), who distinguished in this group of species two genera, viz. Opercularia Gaertn. and Pomax Soland. ex A. Rich., included it as a separate tribe in the Rubiaceae, and this example was followed by DE GANDOLLE in his "Prodromus". Richard rejected the decision taken by de Jussieu, because in his 
opinion the number of stamens would vary in the Rubiaceae and because in that family more examples of genera with unilocular ovaries would occur. Richard, however, was mistaken, for in the genera which on good grounds have been referred to this family the androecium is always isomerous and the ovary is always divided in two or more cells. Exceptions to this rule are found in the genus Eleutheranthus F. v. Müll., which is doubtless a near ally of the genera Opercularia and Pomax, in the genus Tammsia Karst., which will be discussed hereafter, and in some genera which have been included in the Gardenieae, viz. in the type genus Gardenia Ellis and the nearly related genera Macrosphyra Hook, f. and Casasia A. Rich., and also in Villaria Rolfe. However, as RICHARD (op. cit. 214-215) already pointed out, the structures on which in these genera the ovules are inserted, though distinctly separated from each other in the basal part of the ovary, are in the upper part not rarely united; for this reason they can very well be regarded as dissepiments, in which case the ovary would have to be described as imperfectly 2- or more-locular. The genera Opercularia, Pomax and Eleutheranthus ought certainly to be studied in more detail; I expect that such a study will confirm the standpoint of de Jussieu, and that as a further result his family Operculariaceae will prove to belong to the Dipsacales.

Other genera of doubtful position are Tammsia Karst., Pentagonia Bth., Hippotis Ruiz et Pav. and Sommera Schlecht. These four genera were regarded by Schumann (Natürl. Pflanzenfam. IV, 4: 69. 1891) as nearly related because of the peculiar striation of their leaves. This so-called moiré or watered striation, however, is not restricted to these genera, but is found also in the Malesian species of the genus Antirhea Commerc. (see my paper on a South-American species of this genus in Acta Bot. Neerl. 8: 480. 1959), and as to the four genera mentioned in the preceding sentence, it is by no means certain that they may be regarded as nearly related. The genus Tammsia with its unilocular ovary and parietal placentas differs considerably from the three other ones; in combination with the anisomerism between calyx and corolla and the zygomorphism of the latter and of the androecium, these characters make the position of this genus in the Rubiaceae extremely doubtful. Of one of the species of Pentagonia it is said that it has pinnatifid leaves; this too is a character which is never met in the genera which on good grounds have been included in this family, and if this species has correctly been referred to this genus, the latter will doubtless have to be referred to another family. Hippotis and Sommera are less aberrant. The strongly zygomorphic calyx and the less strongly, although still distinctly zygomorphic corolla found in Hippotis, a combination of characters which by Richard (op. cit.: 176) was compared with that met with in the genus Spathodea P. Beauv. (Bignoniaceae), are doubtless unusual features, but they would in themselves not suffice to exclude this genus from the Rubiaceae, and Sommera seems to fit even better in this family. However, before a final decision can be taken, these four genera should be studied in more detail. 
The genus Aitchisonia Hemsl., for which a place has been found in the Paederieae, though on what grounds is not clear, is, on account of the insertion of the stamens at various heights in the corolla tube and of the presence of glandular hairs, certainly to be excluded from this family. As I have pointed out on p. 153 of my "Monographie des genres Cremocarpon Boiv. ex Baill. et Pyragra Brem." (Candollea 16: 147-177. 1958), the combination of raphides and glandular hairs which is found in this genus, is vary rare and does not occur in any other genus provided with interpetiolar stipules and a bilocular ovary with a single ascending ovule in each of the cells. For this reason we will have to assume that Aitchisonia represents an as yet undescribed family, which probably will have to be put in the Dipsacales in the vicinity of the Caprifoliaceae.

The genera Gaertnera Lam. and Pagamea Aubl. were originally included in the Loganiaceae, but were transferred by Baillon and Schumann to the Rubiaceae, where they were placed, on account of the solitary ascending ovules and the valvate aestivation of the corolla lobes, in the Psychotrieae. In my "Notes on the Rubiaceae of Surinam" (Rec. d. trav. bot. néerl. 31: 248. 1934) I returned them to the Loganiaceae, but in my communication to the $8^{\text {th }}$ Botanical Congress held in Paris, of which an abstract was published on p. 113 of the "Rapports et Communications aux Sections 2, 4, 5 et 6: 113. 1954" under the title "Les sous-familles et les tribus des Rubiacées" I changed my attitude with regard to these genera, and accepted the decision taken by Baillon; a strong argument in favour of the view that they are to be included in the Rubiaceae is the presence of stipules provided with colleters, whereas a strong argument in favour of their exclusion from the Loganiaceae is to be found in the absence of intraxylary phloem; the presence of raphides and the valvate aestivation of the corolla lobes prove that they belong to the subfamily Rubioideae.

In my paper of 1934 I also excluded the genus Perama Aubl., wich indeed shows many unusual features, viz. rudimentary stipules, parallel-nerved leaves, the presence of but two calyx lobes, which on account of the position they occupy in the diagram were regarded by BaIllon (Hist. d. Pl. 7: 392 . 1880) as bracteoles, the sometimes trimeric corolla, the trilocular ovary and the triquetrous seeds. The position of this genus was once more discussed by me in the introduction to my work on "The African Species of Oldenlandia L sensu Hiern et K. Schumann" (1952). In a note on p. 13 I pointed out that on account of the presence of raphides the genus is to be included in the subfamily Rubioideae, but that it can not be returned to the Spermacoceae, the tribe in which it had been put by Hooker as well as by Schumann, as it differs from the latter in the ascending ovules, the rudimentary stipules and the structure of the pollen grains, and that it is on account of its many unusual features to be referred to a tribe of its own, the Perameae.

\section{The subdrvision of the Rubiaceae}

If we take into consideration that the family Rubiaceae, as was 
pointed out in the preceding chapter, still contains several genera of which it may rightly be doubted whether their inclusion in this family is justified, it will be no matter of surprise that the delimitation of the groups in which the family was divided in the older works in which a classification of the family was given, was still far from satisfactory, for if it really had been satisfactory, the fact that these genera were included in it and that, as will be shown in this chapter, an even much larger number was referred to the wrong tribe, would be inexplicable. My attempts to correct these mistakes of my predecessors has led to the development of a new classification, but before entering into details, it seems appropriate to give a brief survey of the older ones.

The oldest subdivision of the Rubiaceae which deserves our attention, is that given by DE Jussieu on p. 196 of his "Genera Plantarum" (1789). He distinguished ten groups, mainly on account of the dehiscence or indehiscence of the fruit, the number of locules it contains and the number of seeds in the latter, though the number of stamens, the position of the leaves and the habit are also taken into consideration; in one of the groups, the last one, special emphasis is laid on the form of the inflorescence; it comprises the genera with capitate flowers. Only a few of the groups distinguished by de Jussieu can be regarded as natural or more or less so. Group I (Fructus dicoccus dispermus. Stamina saepius quattuor. Folia plerumque verticillata; caulis plerumque herbaceus) comprises the genera which are now included in the Rubieae (Stellatae, Galieae) and, in addition, the genus Anthospermum. Group II (Fructus dicoccus dispermus. Stamina quattuor, rarius quinque aut sex. Folia saepius opposita, mediante vagina ciliata; caulis plerumque herbaceus) agrees in the main with the Spermacoceae, though the genus Knoxia and, by mistake, the genus Houstonia have also been included. Group III (Fructus monocarpus bilocularis polyspermus. Stamina quattuor. Folia opposita; caulis herbaceus aut frutescens) comprises genera which for the greater part are referred by me to the Hedyotideae. Group IV (Fructus monocarpus bilocularis polyspermus. Stamina quinque. Folia opposita; caulis saepe frutescens) forms a rather unnatural mixture, for it contains genera which at present are referred to the Hedyotideae, the Gardenieae, the Mussaendeae, the Cinchoneae and the Rondeletieae. Group V (Fructus monocarpus bilocularis dispermus. Stamina sex aut plura. Folia opposita; caulis frutescens aut arboreus) comprises but two genera, viz. Hillia and Duroia, of which Hillia occupies a very isolated position in the family, whereas Duroia agrees in all essential points with the Gardenieae. Group VI (Fructus monocarpus bilocularis dispermus. Stamina quattuor. Folia opposita; caulis plerumque frutescens) contains genera which at present are included in the Ixoreae, the Coussareae and the Guettardeae. Group VII (Fructus monocarpus bilocularis dispermus. Stamina quinque. Folia opposita; caulis frutescens aut arboreus) comprises a mixture of genera now included in the Psychotrieae, the Paederieae, the Anthospermeae, the Ixoreae, the Chiocceae and the Vanguerieae and two genera which do not answer the description viz. Chimarrhis and Simira. Group VIII (Fructus monocarpus 
multilocularis loculis monospermis. Stamina quattuor aut quinque aut plura. Folia opposita; caulis saepe frutescens) comprises genera which are now included in the Guettardeae, Chiococceae, Ixoreae, Vanguerieae and Psychotrieae. Group IX (Fructus monocarpus multilocularis loculis polyspermis. Stamina quinque aut plura. Folia saepius opposita; frutices aut herbae) contains but three genera, viz. Hamelia (Hamelieae) Patima and Sabicea (since then included in the Mussaendeae, from where Sabicea was removed by me to a tribe of its own; the position of Patima is still uncertain). Group X (Flores aggregati supra receptaculum commune aut rarius coadunati. Folia opposita; arbores aut frutices, rarius herbae) comprises a number of unrelated genera which are now divided over the Anthospermeae, Gardenieae, Coussareae, Psychotrieae, Morindeae and Naucleeae and one genus of which the position is still uncertain, viz. Cephalanthus. In a remark made on p. 210 he unites these groups in four more comprehensive ones, viz. one with didymous fruits which corresponds with the groups I, II and III, one with two-seeded fruits, corresponding with the groups VI and VII, one with many-seeded fruits, corresponding with the groups IV and V, and one with plurilocular fruits corresponding with the groups VIII and IX; for his group $\mathrm{X}$ there is apparently no place in this classification. De Jussieu's ten groups were accepted with a few additions and emendations by JAUME DE SaINT-Hilaire in his "Exposition des familles naturelles" (I. 2: 428-453. 1805), whereas de Candolle's original division of the Rubiaceae in four tribes, viz. the Stellatae, Coffeaceae, Chinchonaceae and Guettardaceae (Ann. du Mus. 9: 217. 1827) was apparently in the main based on the division made by de Jussieu in the above quoted remark.

In his "Mémoire sur la famille des Rubiaceés" (Paris, 1830) A. RICHARD distinguished 11 tribes, of which the first seven are characterized by the presence of a single ovule in each of the ovary cells, whereas in the four other tribes each of the ovary cells contains several ovules. The tribes with uni-ovular ovary cells are the Asperuleae (= Rubieae), Anthospermeae, Operculariaceae, Spermacoceae (in this tribe the genus Cephalanthus was included), Coffeaceae (contains genera which are now distributed over the Psychotrieae, Coussareae, Paederieae, Ixoreae and Vanguerieae), Guettardaceae (contains the genera with a drupe containing a bi- or plurilocular pyrene or several pyrenes, i.e. apart from the Guettardeae such totally different genera as Saldinia, Nonatelia, Retiniphyllum. Lasianthus and Morinda) and the Cordiereae (said to be intermediate between the Guettardaceae and the Gardeniaceae; it comprises three rather widely different genera, viz. Cordiera, Myrmecodia and Tricalysia). The tribes with pluri-ovular ovary cells are the Hamelieae (agreeing in the main with de Jussieu's group IX), the Isertieae (a small tribe differing from the preceding one in the fruit, which is a drupe containing 4-5 pyrenes; it contains the genera Isertia, Gonzalea (= Gonzalagunia), Metabolus and Anthocephalus), the Gardeniaceae (said to possess a berry with two locules, each with several seeds; it is a mixture of genera belonging to the Gardenieae and the Mussaendeae and contains in addition several genera which belong to 
other tribes or of which the position is still uncertain), and the Cinchoneae (with bilocular capsules with several seeds in each locule; it comprises besides the Cinchoneae genera belonging to the Rondeletieae, the $\mathrm{Nau}$ cleeae and the Hedyotideae and genera occupying an isolated position, like Sickingia and Hillia). Richard based his classification therefore in the main on the number of ovules found in each of the ovary cells and on the nature of the fruit, but the characters by which the various kinds of fruits are distinguished, are morphologically of little or no importance, and practically no attempt has been made to correlate these differences with characters observed in other parts of the plants. It is therefore not to be wondered that but few of the tribes distinguished by him can be accepted as natural ones or more or less natural ones. This applies to the tribes Asperuleae, Anthospermeae, Spermacoceae and perhaps to the Opercularieae.

In the classification elaborated by DE CANDOLle in the "Prodromus" (4: 342-343. 1830) 13 tribes are distinguished, of which the first five agree with each other in the presence of several seeds in the loculi of the fruit, whereas the other eight tribes have but a single seed in each of the loculi. To the first group belong the Cinchonaceae (whith bilocular capsules and winged seeds) subdivided in Naucleae (with sessile fruits) and Cinchoneae (with pedicellate fruits), the Gardeniaceae (with bilocular or occasionally by abortion unilocular fleshy fruits and seeds without wings) subdivided in Sarcocephaleae (with sessile, capitate fruits) and Gardenieae (with pedunculate or sessile, but not capitate fruits), the Hedyotideae (with bilocular capsules and seeds without wings) subdivided in Rondeletieae (with triangular, free stipules) and the Hedyoteae (with stipules that are at the base united into a sheath and at the top split in several narrow processes), the Isertieae (with drupes containing 2-6 pyrenes) and the Hamelieae (with berries containing several locules). The second group comprises the Cordiereae (with baccate, plurilocular fruits), the Guettardaceae (with drupes containing 2-10 pyrenes and cylindrical seeds) subdivided in Morindeae (with capitate or connate fruits) and Guettardeae (with more or less distinctly pedicellate fruits), the Paederieae (with but slightly fleshy fruits of which the fleshy parts are soon lost, after which the two flattened pyrenes remain attached to the top of the bipartite axis; seeds with a fleshy endosperm), the Coffeaceae (fruits said to be bilocular berries with two semiglobose seeds, the latter with a longitudinal groove on the flat side; endosperm horny) subdivided in Coffeae (with distinctly pedicellate fruits) and Cephaelideae (with capitate fruits surrounded by bracts), the Spermacoceae (with more or less dry fruits containing 2 to 4 pyrenes, and with a bilamellar stigma) subdivided in Cephalantheae (with sessile flowers), Euspermacoceae (with pedicellate flowers and fruits splitting into 2-4 mericarps and Putorieae (with a more or less fleshy fruit which does not split), the Anthospermeae (with a more or less dry fruit which splits into two mericarps or, more rarely, fleshy and bilocular, and with long and hairy stigmata), the Stellatae (with a more or less dry fruit which splits into two mericarps or, more rarely, fleshy and bilocular, and with capitate stigmata) 
and the Operculariaceae (with unilocular one-seeded connate fruits which finally open at the top with two valves).

If we compare the classification of de Candolle with that of Richard, we see that two new tribes have been added, viz. the Paederieae, which is to be regarded as a natural one, and the Hedyotideae, which comprises two subtribes, the Rondeletieae and the Hedyoteae, and as these subtribes show but a very superficial resemblance, this tribe is obviously an entirely artificial one. Some of the other tribes too are subdivided, but in the case of the Gardeniaceae, the Guettardaceae and the Coffeaceae these subdivisions merely emphasize the unnaturalness of the tribes which are divided in this way.

In the classification of LindLey (The Vegetable Kingdom: 761 and 768. 1846) the name of the family is changed into Cinchonaceae. This has apparently been done because one of the tribes, viz. that of the Stellatae, has been excluded; this tribe was raised by Lindley to family rank. The tribe Cordiereae has been suppressed, and the name Coffeaceae has been replaced by Psychotridae, but otherwise there are no differences of any importance with the classification of de Candolle.

In Bentham and Hooker's "Genera Plantarum" (II, 1. 1837) Hooker too splits the family on account of the number of ovules per ovary cell, but instead of two main groups, he distinguished three of them. Series A comprises the tribes with pluri-ovular ovary cells, series $B$ those with collateral ovules, and series $\mathbf{C}$ those with uni-ovular ovary cells. Series $A$ and series $G$, moreover, are each subdivided in two subseries; series $A$ according to the nature of the fruit in a subseries with dry fruits and one with fleshy fruits, and series $\mathrm{G}$ according to the position of the embryo in the seed in a subseries in which the radicle points downwards and one in which the radicle points upwards. In the first subseries of series $A$ two of the subtribes created by de Candolle, viz. the Naucleae and the Rondeletieae are raised to the rank of tribes, whereas an entirely new tribe, that of the Henriquezieae, is added; however, the two genera brought together in this tribe show no distinct affinity with the Rubiaceae, and the tribe therefore was excluded by me, and placed in the rank of a family in the vicinity of the Bignoniaceae (see chapter II). In the second subseries de Candolle's Isertieae are suppressed, whereas two new tribes, the Mussaendeae and the Cateshaeeae are added. Series B comprises two tribes, the Cruckshanksieae and the Retiniphylleae, of which the first shows an unmistakable resemblance to the Hedyotideae, a tribe in which it was sunk by Schumann, whereas the second was created for the aberrant genus Retiniphyllum, which by Richard was regarded as a near ally of $\mathcal{N}$ onatelia, whereas it was put by Schumann in the Gardenieae; both authors, however, were mistaken, for as Retiniphyllum has no raphides, it can be no near ally of $\mathcal{N}$ natelia, a genus belonging to the Psychotrieae, and as it does not show the pollination mechanism which is typical for the Gardenieae, it can not be included in the latter either. In the first subseries of series $\mathbf{C}$ the Morindeae are removed from the neighbourhood of the Guettardeae, with which in fact they show no near affinity, and transferred to the second subseries, whereas four new 
tribes are added, viz. the Knoxieae, the Chiococceae, the Alberteae and the Vanguerieae. In the second subseries de Candolle's Coffeae are split into three tribes, viz. the Ixoreae, the Psychotrieae and the Coussareae. In comparing Hooker's classification with that of de Candolle, it strikes us that great importance is attributed to the aestivation of the corolla lobes, a point which in the classification of de Candolle played no part, and which enabled Hooker to separate the Ixoreae from the $P s y-$ chotrieae and the Coussareae, and that in the series with uni-ovular ovary cells attention is paid to the position of the embryo in the seed (radicle either superior or inferior), i.e. to the insertion of the ovules; in the case of the Guettardeae, moreover, the attention is drawn to the absence or poor development of the endosperm. The total number of tribes distinguished by Hooker is 25 against 13 by de Candolle.

The classification adopted by K. Schumann in Engler \& Prantl's "Natürliche Pflanzenfamilien" (IV, 4: 16. 1891) is in the main founded on that of Hooker. Schumann too begins with a division based on the number of ovules, but in contrast with Hooker he accepts but two main groups, for which he introduces the names Cinchonoideae and Coffeoideae. The Cinchonoideae are divided in Cinchoninae (with dry fruits) and Gardeninae (with fleshy fruits), the Coffeoideae on account of the position of the radicle in Guettardinae (radicle superior) and Psychotriinae (radicle inferior). In the Cinchoninae he includes six tribes, viz. the Condamineae, Oldenlandieae (= Hedyotideae), the Rondeletieae, the Cinchoneae, the Henriquezieae and the Naucleeae, the same tribes, therefore, as Hooker included in his subseries 1 of series A. The Gardeninae are divided in two tribes, the Mussaendeae and the Gardenieae, corresponding with the tribes VII and X of subseries 2 of Hooker's series $\mathrm{A}$; the two other tribes which Hooker recognized in this subseries, the Hamelieae and the Catesbaeeae, are included by Schumann in the Gardenieae, which is no improvement, for these tribes have very little in common with each other and with the true Gardenieae. Of the two tribes for which Hooker created his series B, the first, the Cruckshanksieae, are included by Schumann in his Oldenlandieae, with which they are doubtless nearly related, whereas the Retiniphylleae were included by him in his Gardenieae, which, as pointed out above, was a mistake. The Guettardinae correspond to Hooker's series C subseries 1, and comprise the same five tribes, the Alberteae, Knoxieae, Vanguerieae, Guettardeae and Chiococceae. The Psychotriinae similarly correspond to Hooker's series $\mathrm{C}$ subseries 2, and comprise the same eight tribes, viz. the Ixoreae, Psychotrieae, Paederieae, Anthospermeae, Coussareae, Morindeae, Spermacoceae and Galieae. The differences with the classification elaborated by Hooker are therefore but few, and the characters on which the classification rests, are in the main the same.

The classifications discussed above are all based in the first place on the number of ovules per ovary cell, whereas for the subdivision of the main groups much weight was attached to the nature of the fruits, which to this end were distinguished in dry and fleshy ones, a distinction which is morphologically unsound and therefore taxonomically of little or no value, and subsequently also to the position of 
the radicle, which is certainly of importance, but of which nevertheless the importance has been overrated, for the Guettardeae show but little affinity to the other tribes of the Guettardinae, and the Ixoreae show more affinity with the latter than with the other tribes of the Psychotriinae, the group in which they were included by the authors of these classifications. This means that the Guettardinae and the Psychotriinae are to be regarded as artificial groups.

More recently, and so far only tentatively, two new classifications were proposed, which deviate considerably from the older ones. The first of these two new classifications is that which I myself expounded at one of the meetings of the section for taxonomy of the $8^{\text {th }}$ Botanical Congress held in Paris in 1954, but as of this classification only a very brief report was published (Rapports et Communications aux sections $2,4,5$ et $6: 113-114$ ), and as I have since then changed my views on some points, I will first discuss the other one, as of the latter a more detailed report has been published. This is the one proposed by VERDCOURT (Remarks on the classification of the Rubiaceae in Bull. du Jard. bot. de l'État, Bruxelles, 28: 209-281. 1958). Verdcourt distinguishes three subfamilies l.c. 250-252), viz. Rubioideae (raphides present and seeds albuminous), Cinchonoideae (raphides absent and seeds albuminous; hairs never septate) and Guettardoideae (raphides absent, seeds exalbuminous or with traces only of albumen). The Rubioideae are subdivided into Psychotrieae, Coussareae, Morindeae, Schradereae, Urophylleae, Craterispermeae, Knoxieae, Paederieae, Coccocypseleae, Argostemmateae, Ophiorrhizeae, Hamelieae, Cruckshanksieae, Hedyotideae, Anthospermeae, Spermacoceae and Rubieae. This subfamily therefore includes the tribes which were divided by me over two subfamilies, viz. the Rubioideae and the Urophylloideae. The last-mentioned subfamily is included by him on the ground that the styloid crystals of calcium oxalate differ too little from the true raphides, a view with which but few specialists in this field will agree. In my opinion there is very little resemblance between the tribes included in this subfamily and those which were united by me in the subfamily Rubioideae. With the introduction of the new tribe Craterispermeae and with the restoration of the Cruckshanksieae I agree. The Cinchonoideae comprise in Vercourt's delimitation the tribes Naucleeae, Cinchoneae, Rondeletieae (in which the Condamineae are included), Mussaendeae, Catesbaeeae, Gardenieae, Ixoreae (divided in Ixorinae, Cremasporinae and Heinseniinae,) Retiniphylleae, Alberteae, Vanguerieae and Chiococceae. These tribes were for reasons which I will expound hereafter, divided by me over two subfamilies, the Cinchonoideae and the Ixoroideae, which in my opinion have but little in common. The reduction of the tribe Cremasporeae to a subtribe of the Ixoreae is hardly justifiable; the genus Heinsenia was not seen by me, but Verdcourt's remarks on this genus do not prove a near affinity with the Ixoreae. With regard to his reduction of the Condamineae to the Rondeletieae I feel rather sceptical, but $I$ admit that both tribes are very imperfectly known and deserve a thorough revision. In his third subfamily, that of the Guettardoideae, 
he recognizes but one tribe, the Guettardeae. In this point there is full agreement between his classification and mine.

I will now give a summary of the remarks on the classification of the Rubiaceae made by me in various papers on genera or groups of genera belonging to this family, and expound the classification at which I have finally arrived. This, however, is still a provisional one, for there are still a considerable number of genera of which the position remains uncertain. As I am unable to continue my work in this field, I must leave the study of these genera to others.

In the above-mentioned paper read at the $8^{\text {th }}$ Botanical Congress I distinguished six subfamilies, viz. the Cinchonoideae, the Urophylloideae, the Ophiorrhizoideae, the Guettardoideae, the Ixoroideae and the Rubioideae. Since then I have added a seventh subfamily, that of the Gleasonioideae (see my paper "On the position of Platycarpum Humb. et Bonpl., Henriquezia Spruce ex Bth. and Gleasonia Standl." in Acta Bot. Neerl. 6: $351-377$. 1957), and in the present publication I will add an eighth one, the Hillioideae. Here, moreover, one of the tribes included in the Ophiorrhizoideae, the Ophiorrhizeae, is transferred to the Urophylloideae, so that for the remaining tribe, the Pomazoteae a new subfamily name had to be coined, viz. Pomazotoideae.

The Cinchonoideae are in the delimitation proposed by me easily recognizable by the structure of the testa, which consists of cells with vary large pits, occasionally accompanied by the ordinary, very minute ones; the large pits, however, are always confined to the basal wall; in the very thick lateral walls they are totally lacking. A second important diagnostic character is to be found in the elongated form of the placenta. Other general characters, though not confined to this subfamily, are the always multiovular ovary cells and the absence of raphides. Genera which show another kind of placentation and whose testa cells show another kind of sculpture, and, of course, also those in which raphides are present, should be excluded. This applies e.g. to the genus which for a long time was known as Sickingia Willd., but of which the correct name is Simira Aubl. (see my paper on "The identity of Simira tinctoria Aubl. in Acta Bot. Neerl. 3: 150-153. 1954), to the genus Gleasonia Standl., to the Hedyotideae and to several genera provided with raphides which were included in the other tribes; these genera do not show the typical structure of the testa cells found in the true Cinchonoideae nor the type of placentation which is characteristic for the latter.

The Urophylloideae are still imperfectly characterizable. Their most striking feature are the large, thick-walled testa cells which differ from those found in the Cinchonoideae by the absence of the peculiar large pits which are typical for that subfamily. Testa cells of the same kind as those of the Urophylloideae, however, are found also in the Coccocypseleae and the Schradereae, tribes which differ from those included in the Urophylloideae by the presence of raphides. That this kind of crystals would be present in Urophyllum Wall., as reported by Solereder, 
is a mistake; in this genus and its allies calcium oxalate is present in the form of styloids.

The third subfamily, that of the Pomazotoideae, is characterized by a testa consisting of cells of which the basal wall shows an unusual kind of dots, which seem to consist of bundles of very small pits. In this subfamily too the ovary cells are always pluri-ovular and raphides are always absent.

The fourth subfamily is that of the Gleasonioideae. It agrees with the next subfamily, that of the Guettardoideae, in the exalbuminous seeds, but differs from them, and indeed from all other subfamilies of the Rubiaceae in the large size of the cotyledons. Other points of difference with the Guettardoideae are the absence of crystals in the wall of the hairs, the pluri-ovular ovary cells and the capsular fruit. In the wall structure of the testa cells they show some resemblance to the Hillioideae, with which they agree also in the pluri-ovular ovary cells and in the capsular fruits, but from which they differ in the absence of raphides, in the loculicidally dehiscent capsule and in the absence of the tuft of hairs at the top of the seed.

The fifth subfamily, that of the Guettardoideae agrees, as stated above, with the preceding subfamily in the exalbuminous seeds, but it differs conspicuously from the latter in the smaller size of the cotyledons, the uni-ovular ovary cells and the drupaceous fruits. A character in which this subtribe differs from all the other ones, is the presence of crystals of calcium oxalate in the wall of the hairs with which the various parts are covered. These crystals are absent only in the genus Machaonia, which, however, on account of the entirely different fruits, is to be excluded. In this subfamily too raphides are always absent.

The sixth subfamily, that of the Ixoroideae, comprises all those tribes in which the upper part of the style acts as a receptaculum pollinis, which means that the hairs by which it is covered, collect already before the flower opens, the pollen from the anthers; when the flower opens, the pollen grains can be removed by visiting insects, which may transport them to flowers which have reached the stage in which the stigmata are ready to receive them. Other important characters, though not confined to this subfamily, are the simple interpetiolar stipules, the insertion of the stamens in the corolla throat and the absence of raphides. At one time I thought that the pollination mechanism which is characteristic for this subfamily, was found also in the Naucleeae in their former delimitation and in the genus Cephalanthus, but this view afterwards appeared to be erroneous.

The seventh subfamily is that of the Rubioideae, which are characterized by the presence of raphides, a feature which it shares with the next subfamily, that of the Hillioideae, and by the either valvate or, rarely, imbricate aestivation of the corolla lobes. 
The eighth and, at least for the moment, last subfamily, the Hillioideae, agrees, as stated above, with the preceding one in the presence of raphides, but differs from the latter by the contorted aestivation of the corolla lobes and from all other Rubiaceae in the presence of a tuft of hairs at the top of the seed. In the structure of the testa cells it shows some resemblance with the Gleasonioideae or it least to those species of Gleasonia of which fully mature seeds were available.

Of these eight subfamilies the Chinchonoideae, Gleasonioideae, Guettardoideae, Ixoroideae, Rubioideae and Hillioideae are doubtless natural groups, but this can not yet be said with the same degree of certitude of the Urophylloideae and the Pomazotoideae, for although the tribes that are referred to them, can apparently not be accommodated in any of the other subfamilies, it is as yet not fully certain that the points in which they agree, are of sufficient importance to unite some of them in a more comprehensive group.

Now that a preliminary survey of the subfamilies has been given, we will turn our attention to the tribes for whose accommodation they were established.

In the Cinchonoidea I include seven tribes, the Cinchoneae, the Naucleeae, the Condamineae, the Rondeletieae, the Sipaneae, the Mussaendeae and the Sabiceeae. In my paper read at the $8^{\text {th }}$ Botanical Congress I included in this subfamily also a tribe which I called the Manettieae, but this was an inaccuracy, for, as I had pointed out already in my work on "The African Species of Oldenlandia" (p. 14), the genus Manettia $L$ is in the possession of raphides, and is therefore to be included in the Rubioideae.

The Cinchoneae were in the delimitation accepted by the older authors a rather artificial conglomerate of genera. A comparatively large number of them are to be excluded on account of the presence of raphides. These genera are (see "The African Species of Oldenlandia", p. 14) Bouvardia Salisb., Heterophyllaea Hook. f., Hindsia Bth., Hymenopogon Wall., Manettia L, Danais Commerc. ex Vent., Coursiana Homolle and Hillia Jacq.; they were included in this tribe either on account of their winged seeds, a character which is of little importance so long as it is not proved that the wings may be regarded everywhere as homologous structures, or else (Hillia) because of their adnate placentas. Other genera that are to be removed, are Crossopteryx Fenzl and Coptosapelta Korth.; as these genera show the pollination mechanism which is typical for the Ixoroideae, they will have to be included in that subfamily. Coptosapelta would, according to Solereder, be provided with raphides, but this is a mistake. The position of some other genera is still uncertain. On the other hand, most of the genera which so far have been included in the Naucleeae, will have to be removed to the Cinchoneae, as they differ from the other genera of 
this tribe in the capituliform inflorescence only. These genera are Adina Salisb., Mitragyne Korth., Uncaria Schreb., Neonauclea Merr. and probably also Anthocephalus A. Rich. and Breonia A. Rich. On account of the capituliform inflorescence they might perhaps be united in a subtribe.

The Naucleeae are restricted by me to the genus $\mathcal{N a u c l e a} \mathrm{L}$ in the sense in which it was defined by Merrill, i.e. as congeneric with Sarcocephalus Afzel. In this delimitation they are characterized by the presence of connate ovaries, fleshy compound fruits and but slightly winged seeds. The testa has not yet been studied, so that it is not fully certain that the inclusion of this tribe in the Cinchonoideae is justified. The position of the genus Cephalanthus $\mathrm{L}$ remains as yet uncertain. As each of the ovary cells contains but a single, pendulous ovule, it is very doubtful whether this genus can be included in the Cinchonoideae. It has sometimes been referred to the Spermacoceae, but this is certainly a mistake, as the ovules are not attached to the middle of the dissepiment, but to its top. Before its position can be determined, this genus will have to be studied in more detail.

The Condamineae differ from the Cinchoneae in the horizontal, not vertical, position of the ovules and in the not or but slightly winged seeds. In these two characters they agree with the Rondeletieae, from which they differ in the valvate aestivation of the corolla lobes.

The Rondeletieae differ from the Condamineae in the aestivation of the corolla lobes, which in this tribe is either imbricate or contorted. However, as these two types of aestivation are, in contrast to imbricate and valvate, but rarely met with in nearly related genera, it is not impossible that further study will lead to a splitting up of this tribe. Of the genera which so far have been included in the Rondeletieae, some will have to be removed for other reasons. This applies to the genus Deppea Cham. et Schlecht., which according to Solereder is provided with raphides, Sickingia Willd., which as I have shown elsewhere, is identical with Simira Aubl., and which on account of the structure of the testa is removed by me to the Urophylloideae, Gleasonia Standl., which is the type of my subfamily Gleasonioideae, and Sipanea Aubl. and Limnosipanea Hook. f., which on account of their herbaceous growth, a very unusual feature in the Cinchonoideae, are transferred to a tribe Sipaneae.

The Sipaneae are a small tribe containing but three genera; on account of their herbaceous growth they occupy a somewhat isolated position in the subfamily. These genera are Sipanea Aubl., Virecta Vahl and Limnosipanea Hook. f.

The Mussaendeae too are in my delimitation but a small tribe. Apart from the genus Mussaenda $\mathrm{L}$ and its nearest allies, the genera Aphaenandra Miq. and Asemanthia Ridl. it comprises the genera Isertia Schreb. and Cassupa Humb. et Bonpl. and perhaps a few other ones 
which are less well known, but the great majority of the genera which by the earlier authors were included in this tribe, are to be transferred to other ones, often even to tribes belonging to other subfamilies; some of them do not even belong to the Rubiaceae. The characteristic features of the genera which are left by me in the Mussaendeae, are the bifid or bipartite stipules, the valvate aestivation of the corolla lobes and the insertion of the ovules on a discoid placenta. Of the genera which were included in this tribe by Schumann, Schradera Vahl, Lucinaea DG, Mycetia Reinw., Myrioneuron R. Br. and Coccocypselum [P. Br.] Sw. are on account of the presence of raphides to be removed to the Rubioideae, whereas Acranthera Arn. ex Meisn., Coptophyllum Korth. ${ }^{1}$ ), Pleiocarpidia K. Sch. (Aulacodiscus Hook. f. non Ehrenb.), Urophyllum

1) The name Coptophyllum Korth. used by Miquel for two specuies belonging to the genus Pomazota Ridl. should be rejected. In my "Monograph of the genus Pomazota Ridley" (Journ. Arnold Arbor. 28: 186-203.1947) I did this because Coptophyllum Korth. is a later homonym of Coptophyllum Gardner. I overlooked at that time that Coptophyllum Korth. is inserted in the list of nomina generica conservanda; in fact, it never occurred to me that the name of a genus of which but three species had been described, all of them, moreover, plants which had but rarely been mentioned in the literature, might have been entered in this list! For the same reason I did not go very deeply into the question of the generic identity of the species described by Korthals; I even included it provisorily in Pomazota, viz. with the remark that it was a "species non satis nota". As since then, however, some new combinations in the genus Coptophyllum Korth. have been proposed, it seems indicated to discuss this question somewhat more in detail.

The type specimen of the species on which Coptophyllum Korth. was founded, is no longer available, and was probably already lost at the time at which Miquel described a second species. The description of the type species is very incomplete, so incomplete that it will be difficult and probably even impossible to identify this species. In the description of the first of the two species which were included by Miquel in this genus, the generic name was provided with an interrogation mark. That Miquel was not certain that this species really belonged to the same genus as the plant described by Korthals, evidently means that he had to rely only on the description of the latter, which, as stated above, is very incomplete. If he had seen the type specimen, he would not have felt any doubt, for Pomazota is an easily recognizable genus. That Miquel omitted the interrogation mark when he described his second species, is probably to be explained by assuming that he compared it with his first species and found it to be congeneric with that one.

If I am right in assuming that Miquel had to rely only on the description given by Korthals, and it seems to me that this can hardly be doubted, then he must have been struck by the fact that the corolla was described by Korthals as naked inside, the stipules as obtuse and the fruit as indehiscent, characters that are not found in the two species described by himself, and, in fact, in none of the other species described in the genus Pomazota; it is true, however, that Korthals put an interrogation mark behind "indehiscens".

Now, is it permitted to assume that there can be no doubt with regard to the taxonomic identity of the genus described by Korthals? This question can certainly not be answered in the affirmative, and we will therefore have to admit that Miquel made a mistake in referring his two new species to this genus of doubtful identity.

It is possible, of course, that Korthals made a mistake in describing the inside of the corolla tube as naked and another one in describing the stipules as obtuse, but in order to prove this we would have to produce specimens which in all other respects would agree with the description given by Korthals, and such specimens have as yet not been found. We will have to concede therefore that Coptophyllum Korth. is an unidentifiable name, and that its inclusion in the list of nomina generica conservanda was not justified. For the two species described by Miquel the generic name Pomazota has to be accepted. 
Wall., Pauridiantha Hook. f. and Praravinia Korth. have to be excluded because their testa cells do not show the structure which is typical for the subfamily to which the Mussaendeae belong; the position of the genera Tammsia Karst., Pentagonia Bth., Hippotis Ruiz et Pav. and Sommera Schlecht. is, as was pointed out in chapter II, as yet uncertain; of Tammsia it is even very dubious whether it can be left in the family.

The Sabiceeae are excluded by me from the Mussaendeae because of the simple stipules, the axillary inflorescences and the very narrow testa cells. This tribe contains but a single genus, viz. Sabicea Aubl.

In the Urophylloideae I include the Urophylleae, the Pauridiantheae and, provisionally, the Simireae and the Ophiorrhizeae. Whether Verdcourt's Heinsiinae, which were included by him in the Mussaendeae, may perhaps be shifted to this subfamily, in which case this subtribe would have to be raised to the rank of a tribe, remains to be seen. Following Schumann's example. I would include in this taxon besides the genus Heinsia DC the genus Bertiera Aubl. The testa cells of Bertiera (The African Species of Oldenlandia, Tab. VIIb) agree in structure with those of the Urophylloideae (op. cit. Tab. IV b-h and Tab. Vb).

The Urophylleae are characterized by their dioecism, the plurilocular ovary with in each ovary cell two fully distinct, subpeltate placentas which are attached near the axis and shift as the fruit is ripening to the central part of the dissepiment, and the more or less distinctly spreading stigmata. This tribe comprises the genera Urophyllum Wall., Antherostele Brem., Didymopogon Brem., Maschalocorymbus Brem., Pravinaria Brem., Praravinia Korth., Raphidura Brem., Leucolophus Brem., Lepidostoma Brem., Crobylanthus Brem., Pleiocarpidia K. Sch. and Stichianthus Val.

The Pauridiantheae have bisexual, heterostylous flowers, a usually bilocular, more rarely a quadri- or a quinquelocular ovary with in each of the cells a false dissepiment extending from the top for some distance downwards, axillary placentas which at the top are incised by the false dissepiment and show therefore an obcordate shape, and stigmata which are either cohering or free, but never spreading. To this tribe belong the genera Pauridiantha Hook. f., Pampletantha Brem., Stelechantha Brem., Commitheca Brem., Poecilocalyx Brem. and Rhipidantha Brem. and possibly also Temnopteryx Hook. f. and Pentaloncha Hook. f.

The Simireae comprise but a single genus, viz. Simira Aubl., better known under the name Sickingia Willd. (see my paper on "The identity of Simira tinctoria Aubl. in Acta Bot. Neerl. 3: 130-133. 1954). This genus shows in the structure of its testa cells a striking resemblance with the genera belonging to the two preceding tribes, but in other respects it differs considerably from them. Its most striking 
characters are found in the way in which the ovules are inserted on the placenta and in the large seeds which in the upper half extend into a wing. On account of the horizontal position of the ovules Sickingia was originally referred to the Rondeletieae, but in reality the resemblance is rather superficial, for the number of the ovules is much smaller than in the Rondeletieae and they form but two rows. The form and the mode of insertion of the wing is quite different from that found in the seeds of any other member of the family. The genus doubtless occupies a very isolated position in the family, but in order to decide whether it has correctly been referred to the Urophylloideae or not, it will have to be studied in more detail.

The same applies to the three genera which by me were included in the Ophiorrhizeae, viz. Ophiorrhiza L, Spiradiclis Bl. and Virectaria Brem. On account of the thick-walled testa cells they are provisionally referred to this subfamily. In the structure of the testa cells they show a very striking similarity (The African Species of Oldenlandia: Tab. IV a, b and c), but in other respects they differ rather conspicuously. According to Verdcourt Ophiorrhiza would contain raphides, but it is not impossible that he mistook styloid crystals for raphides. Of Spiradiclis, however, he says "leaves contain optically active oblongs which separate into numerous needle-shaped crystals", so that we will have to assume that here indeed raphides are present. In that case this genus at least would have to be returned to the Hedyotideae.

The Pomazotoideae contain so far but a single tribe, the Pomazoteae, which is characterized by a testa consisting of thin-walled cells with a basal wall which is either minutely dotted or more or less coarsely tuberculate. It comprises the genera Pomazota Ridl. (The African Species of Oldenlandia: Tab. IV i), Klossia Ridl., Siderobombyx Brem., Xanthophytum Reinw. ex Bl. (op. cit. Tab. VI f), Lerchea L (op. cit. Tab. IV j) and perhaps also Paedicalyx Pierre ex Pitard, Keenania Hook. f., Campanocalyx Val., Polysolenia Hook. f. and Leptomischus Drake. Most of these genera are still very imperfectly known; some of them were originally included in the Hedyotideae, from which they had to be removed on account of the absence of raphides, whereas others had been referred to the Mussaendeae, from which, as stated above, they differ in the structure of the testa.

The Gleasonioideae contain so far but a single genus, though it is not excluded that the species which so far have been referred to the latter, will prove to belong to more than one genus. The testa of Gleasonia macrocalyx Ducke is provided with most peculiar wartlets each consisting of several cells, but the structure of the mature cellwall could as yet not be studied as the available seeds were too young. In the two species of which ripe seeds were available, viz. G. duidana Standl., the type species, and $G$. uaupensis Ducke, the testa does not show any wartlets, but the walls show a distinct network of cross-bars (see my paper "On the position of Platycarpum Humb. et Bonpl., 
Henriquezia Spruce ex Bth. and Gleasonia Standl. in Acta Bot. Neerl. 6: 351-377. 1957, fig. 7). The pollen grains are in this genus larger than in any other genus of the Rubiaceae in which they could be measured, and they are, moreover, united in tetrads (op. cit. fig. 3). Pollen grains that are united in tetrads, however, are not confined to this genus; they are e.g. a general feature in the genus Randia (Houst.) L sensu Fagerlind.

The fifth subfamily, that of the Guettardoideae, also contains but one tribe, that of the Guettardeae, but this tribe comprises a larger number of genera than the two preceding subfamilies. Of the genera which were included in this tribe by Schumann, Machaonia can, as stated above, not be maintained in this subfamily, and whether Timonius Rumph. (= Abbottia F. v. Müll.) with its totally different ovaries and fruits has rightly been referred to the same tribe as Guettarda L, looks very dubious.

In the sixth subfamily, the Ixoroideae, a quite considerable number of tribes are to be included, viz. the Coptosapelteae, Acranthereae, Cremasporeae, Gardenieae, Ixoreae, Chiococceae and Vanguerieae.

The tribe of the Coptosapelteae comprises in my delimitation the genera Coptosapelta Korth. and Crossopteryx Fenzl. According to VERDCOURT (l.c.: 239), the latter would have testa cells of which the wall is "pitted as in Cinchona", but this is an error, for the pits are smaller than in the latter, and they are, moreover, not confined to the basal ball, but are found also in the lateral ones (see his plate XVI, fig. Q). In Hymenodictyon Wall. and Corynanthe Welw., which, according to Verdcourt, would have the same pollination mechanism as Coptosapelta and Crossopteryx, the upper part of the style is not distinctly swollen and lacks the short hairs which in the Ixoroideae enable this part to function as receptaculum pollinis. Hymenodictyon and Corynanthe, moreover, can not be regarded as near allies of Coptosapelta and Crossopteryx, for the aestivation of their corolla lobes is valvate, whereas it is in Coptosapelta and Crossopteryx contorted. Other characteristic features of Coptosapelta and Crossopteryx are the subglobose capsules, the pluriovular ovary cells and the short stipules.

The Acranthereae contain but a single genus, viz. Acranthera Arn. ex Meisn. (see my "Monograph of the genus Acranthera Arn. ex Meisn. in Journ. of the Arnold Arbor. 28: 261-308. 1947). In this genus the receptaculum pollinis "remains included between the empty anthers and can be reached only through the windows between the projecting tips of the connectives" (1.c.: 273). On the same page I remarked "the connection of the stamens by means of the projecting tips of the connectives with the top of the style is a feature so entirely unparalleled in the Rubiaceae that one might feel inclined to regard the position of the genus with regard to the rest of the family as similar to that of the Asclepiadaceae with regard to the Apocynaceae, although in this way the importance of the connection between the 
anthers and the style is doubtless over-emphasized. It is perhaps more readily comparable to the way in which in the genera Ceropegia $\mathbf{L}$ and Dichaelia Harv. (Asclepiadaceae) the corolla-tips cohere." Other characteristic features of the species belonging to this genus are the herbaceous growth, the bilocular ovary with in each cell two elongated placentas inserted near the axis and attached over their whole length to the dissepiment, the reduplicate-valvate aestivation of the corolla lobes, the insertion of the stamens near the base of the corolla tube, the usually baccate, rarely more or less capsular fruits and the numerous small seeds provided with a fleshy endosperm and with a testa consisting of cells with a very densely punctate wall.

My next tribe is that of the Cremasporeae, which in the main agrees with the Alberteae of previous authors, but does not include the genera Alberta E. Mey, Nematostylis Hook. f. and Belonophora Hook. f. Verdcourt (1.c.: 248) also excludes Heinsenia K. Sch. and Lamprothamnus Hiern. Heinsenia may be allied to Belonophora, but the arguments on account of which Lamprothamnus was excluded by him, are not fully convincing. Before the exact position of these genera can be determined, they will have to be studied in more detail. The three first-mentioned genera were excluded by me because they do not show the pollination mechanism which is typical for the Ixoroideae. According to Verdcourt this would be an example of degeneration of the typical mechanism, but for this assumption no grounds are adduced. The typical Cremasporeae are characterized by the presence of a single pendulous ovule in each of the cells of the bilocular ovary and by the contorted aestivation of the corolla lobes.

The Gardenieae are in my delimitation a much smaller group than in that accepted by my predecessors. The delimitation given to this tribe by Hooker was widened by Schumann, who included in it the Hamelieae, a tribe of rather unnatural composition which nevertheless had been accepted by all his predecessors since the time of de Jussieu. The type of this taxon, the genus Hamelia Jacq., was removed by me, on account of the presence of raphides, to the subfamily Rubioideae. In the delimitation accepted by Hooker and in that accepted by Schumann the tribe of the Gardenieae comprises the genera Tarenna Gaertn. (=Webera Schrel. and Chomelia L.), Enterospermum Hiern., Tricalysia A. Rich., Empogona Hook. f. and Morelia A. Rich., which, on account of the structure of the drupe, were transferred by me to the Ixoreae (see p. 6-11 of my "Monograph of the genus Pavetta L" in Fedde's Repert. 37: 1-208. 1934). Other genera that are to be excluded, are Posoqueria Aubl. and the related genus Cladoceras Brem. (in Hooker's Icones Plantarum t. 3411. 1940), which possess an entirely different pollination mechanism; the exact position of these two genera remains as yet uncertain. The true Gardenieae are easily recognizable by their many-seeded, comparatively large fruits which are provided with a thick, leathery or more or less woody pericarp and a gelatinous endocarp in which the numerous seeds are 
embedded. They are not rarely dioecious, in which case the male flowers are provided with a style of which the upper part serves as "receptaculum pollinis" (see my remarks on this group of genera in my "Monograph of the genus Pavetta L" p. 11-12). Fruits of the kind described above are found in the genera Gardenia Ellis, Randia Houst., Rosenbergiodendron Fagerl., Tocoyena Aubl., Genipa L, Alibertia A. Rich., Ibetralia Brem., Duroia L. f. and perhaps some other ones.

The Ixoreae are in my delimitation a larger group than in that of my predecessors, who restricted this tribe to genera with uni-ovular ovary cells. As the number of ovules per ovary cell appeared to vary in perfectly natural genera from one to two (Pavetta $\mathrm{L}$ ) or from one tọ several (Tarenna Gaertn.), this restriction was dropped by me, and a comparatively large number of genera were, as stated above, transferred from the Gardenieae to this tribe. The two tribes resemble each other in the contorted aestivation of the corolla lobes. This is doubtless an important character, and for this reason the genera Phyllomelia Griseb. and Strumpfia Jacq., which show an imbricate aestivation of the corolla lobes, are to be excluded. Hooker said of these genera that they were "dubiae affinitatis", and today too the question of their taxonomic position has not yet been decided. Some other genera of doubtful position were discussed in my "Monograph of the genus Pavetta L", p. 8 and 9.

In the Chiococceae the ovary cells are always uni-ovular and the ovules always pendulous; another noteworthy feature is the insertion of the stamens near the base of the corolla tube. The only exception to this rule is found in the genus Placocarpa Hook. f. which for this reason will have to be excluded. The aestivation of the corolla lobes is either valvate or imbricate.

The last tribe to be included in this subfamily are the Vanguerieae. The genera belonging to this tribe resemble those belonging to the Chiococceae in the uni-ovular ovary cells and the pendulous ovules, which however are, as a rule, inserted below the top of the dissepiment; with the majority of these genera they agree furthermore in the valvate aestivation of the corolla lobes. One of the two most important points of difference between these two tribes is found in the insertion of the stamens; in the Chiococceae they are always inserted near the base of the corolla tube, in the Vanguerieae always in the corolla throat. The other important difference is found in the form of the "receptaculum pollinis", which in the Vanguerieae is short and swollen and at the base usually more or less free from the rest of the style, whereas it shows in the Chiococceae the same elongated, but slightly swollen form as in the other tribes of this subfamily: The genus Craterispermum Bth. lacks the swelling at the top of the style, and as it is provided with raphides and with heterostylous flowers it was removed by Verdcourt to the Rubioideae. 
The Rubioideae are the largest subfamily of the Rubiaceae, and comprise in the survey given in this paper no less than nineteen tribes, and this number will probably increase when the genera of doubtful position become better known. They are, as we have seen, characterized by the presence of raphides and by the valvate or, rarely, imbricate aestivation of the corolla lobes. The only other subfamily in which the presence of raphides has been reported, is that created for the accommodation of the aberrant genus Hillia Jacq., where the corolla lobes show a contorted aestivation. The nineteen subfamilies of the Rubioideae are the Hedyotideae, Cruckshanksieae, Argostemmatideae, Coccocypseleae, Schradereae, Hamelieae, Spermacoceae, Anthospermeae, Rubieae, Perameae, Psychotrieae, Triainolepideae, Lathraeocarpeae, Gaertnereae, Coussareae, Paederieae, Morindeae, Knoxieae and Craterispermeae.

The Hedyotideae are by far the largest tribe of this subfamily. They comprise in my delimitation the genera which show a valvate aestivation of the corolla lobes, a character in which they agree with most of the other tribes, pluri-ovular ovary cells, a feature which returns in several other ones, a peltate placenta attached to the middle of the dissepiment, a mode of attachment which is found also in the Hamelieae, non-connivent anthers opening by slits, a point in which they differ from the Argostemmatideae, and a testa consisting of cells with a thin or at least not very thick wall. In my work on "The African Species of Oldenlandia" I transferred the genera Bouvardia Salisb., Heterophyllaea Hook. f., Hindsia Bth., Manettia Mutis ex L, Danais Commerc. ex Vent., Coursiana Homolle, Hymenopogon Wall., Myrioneuron $\mathrm{R}$. Br. and Mycetia Reinw. from the Cinchonoideae to the Hedyotideae. The first seven genera had, on account of the winged seeds, been included in the Cinchoneae, whereas Myrioneuron and Mycetia, on account of their fleshy fruits, had been included in the Mussaendeae; all these genera, however, possess raphides and a testa consisting of cells which lack the large pits which are characteristic for the Cinchonoideae. Myrioneuron and Mycetia occupy a somewhat isolated position in the Hedyotideae on account of the fleshy fruits and on account of the simple, oblong stipules.

The genera that were excluded by me from the Hedyotideae comprise Lerchea L, Pomazota Ridl. and Xanthophytum Reinw. ex Bl., which were transferred to the Pomazotoideae, Virectaria Brem., Spiradiclis Bl. and Ophiorrhiza L, which were removed to the Ophiorrhizeae, a tribe which was provisionally included by me in the Urophylloideae, Carlemannia Bth. and Sylvianthus Hook. f., which, as pointed out in Chapter II, are to be excluded from the family, the genera Carphalea Juss.; Cruckshanksia Hook. et Arn., Dirichletia Klotzsch, Anotis DG and Jackia Wall., which on account of the placenta arising from the basal part of the dissepiment and the small number of ovules are included in the Cruckshanksieae, and Argostemma Wall., Clarkella Hook. f. and perhaps $\mathcal{N}$ eurocalyx Hook. $f$., which on account of their connivent anthers and the insertion of the stamens on the basal part of the corolla tube are referred to a tribe Argostemmatideae. The position of the genus 
Neurocalyx is not yet clear. If AIRy Shaw's section Thyrsoideae (Kew Bull. 1937: 281) really belongs to this genus, it will have to be transferred to the Rondeletieae, for in this section the walls of the testa cells show the structure which is typical for the Cinchonoideae (see "The African Species of Oldenlandia" Tab. II f).

The Cruckshanksieae, a tribe first recognized by Hooker, differ as stated above, from the Heydyotideae by the small number of ovules in the ovary cells ( 1 to 3 or 4 ) and the rod-like placentas rising from the base of the dissepiment. To this tribe belong the genera Cruckshanksia Hook. et Arn., Carphalea Juss., Anotis DG and probably the imperfectly known Jackia Wall. The genus Dirichletia Klotzsch is, according to Homolle (Bull. Soc. Bot. 93: 613. 1936), identical with Carphalea.

The Argostemmatideae differ from the Hedyotideae in the connivent anthers opening with a short slit or a pore and in the insertion of the stamens at the base of the corolla tube. To this tribe belong the nearly related genera Argostemma Wall. and Clarkella Hook. f. and perhaps Neurocalyx Hook. f. (see the remarks made above on the position of the section Thyrsoideae).

The Coccocypseleae differ from the Hedyotideae in the simple stipules, the subcapitate flowers and the structure of the testa cells with their thick walls ("The African Species of Oldenlandia" Tab. III g), which are of the same type as those found in the Schradereae (op. cit. Tab. III $h$ and i). To this tribe belong the genera Coccocypselum [P. Br.] Sw. and Lipostoma D. Don.

The Schradereae are the most deviating tribe among the Rubioideae with pluri-ovular ovary cells and valvate aestivation of the corolla lobes. The two genera included in this tribe, viz. Schradera Vahl and Lucinaea DG, were originally referred to the Mussaendeae. They are glabrous epiphytic shrublets with rather thick shoots, fleshy leaves and large deciduous stipules, usually climbing by means of adhesive rootlets; the inflorescences are capituliform; the flowers are provided with a cupular calyx; the fruits are baccate and the seeds are provided with a testa consisting of thick-walled cells which show a close resemblance to the testa cells of Coccocypselum.

The Hamelieae are in my delimitation restricted to the genera Hamelia Jacq. and Hoffmannia Sw., i.e. to those in which raphides are present. They resemble the preceding tribes in the pluri-ovular ovary cells, but differ from them in the imbricate aestivation of the corolla lobes. The difference between the valvate and the imbricate aestivation of the corolla lobes, however, is apparently of less importance than that between these two types of aestivation and the contorted one; in the Psychotrieae in which the aestivation is normally valvate, we meet at least two genera in which it is imbricate. For this reason the 
rather aberrant structure of the inflorescence found in the Hamelieae, a cyme with monochasial branches, is perhaps of more importance. The two genera, however, should be studied in more detail.

In the now following tribes the ovary cells contain but a single or, exceptionally (Triainolepideae), two or three collateral ovules and the aestivation is, with the exception of the genera Naletonia Brem. and Notopleura Brem. belonging to the Psychotrieae, where it is imbricate, always valvate.

The Spermacoceae are characterized by ovules which are attached to the middle of the dissepiment; in the seed the radicle points downwards, and in this respect there is agreement with the following tribes with the exception of the Knoxieae and the Craterispermeae where the radicle points upwards. The flowers are usually though not always 4-merous, and the fruits are either schizocarpous or capsular. The stipules are united in a truncate cylindrical sheath fringed with filiform appendages. The pollen grains are oblate and usually pluricolpate with short colpae. The genus Perama Aubl. was excluded because of its parallel-nerved leaves, rudimentary stipules, the two-lobed calyx, the pendulous ovules and the globose tricolporate pollen grains.

The Anthospermeae differ from the Spermacoceae in the position of the ovules, which are inserted on the basal part of the dissepiment; in this respect they resemble the following tribes with the exception of the Knoxieae and Craterispermeae. The style is usually split in two very long stigmata, and the stamens are usually inserted on the basal part of the corolla tube, but like the stigmata they project far beyond the mouth of the tube. The genera Eleutheranthus F. v. Müll., Opercularia Gaertn. and Pomax Soland., all three with unilocular ovaries, are apparently to be excluded, but before their position can be determined, they should be studied in more detail. The genus Cremocarpon Boiv. ex Boill. was transferred by me, on account of the horny endosperm, to the Psychotrieae (see my "Monographie des genres Cremocarpon Boiv. ex Baill. et Pyragra Brem." in Candollea 16: 147-177. 1958). In the true Anthospermeae the endosperm is always fleshy.

The Rubieae, originally known as the Stellatae and afterwards as the Galieae, are characterized by the usually verticillate leaves, the rudimentary stipules, the usually rudimentary calyx, the didymous or by abortion occasionally globose fruits, the seeds adhering to the pericarp, the often strongly curved embryo and the globose pluricolpate pollen grains with their long colpae. That the stipules would not be rudimentary but on the contrary strongly developed and transformed into parts which are indistinguishable from true leaves, does not look very probable to me, as in the few Galium species which possess decussate leaves, distinct though small stipules are present, and as in the species with verticillate leaves never intermediate structures are met with. That at the nodes never more than two 
axillary shoots are formed, can not be regarded as a valuable argument for the stipular nature of the leaves which do not bear shoots in their axil, for in plants with verticillate leaves but rarely more than one or two of the axillary buds found at the same node develop into shoots. That the leaves may occur in whorls of 6 as well as of 8 , and occasionally even of 7 , is not favourable either for the view that part of them are stipules. Of the genera which so far have been included in this tribe Didymaea Hook. f. seems to be the only one of dubious position; it has well-developed stipules and seeds which do not adhere to the pericarp; it might perhaps be transferred to the Anthospermeae, but this deserves further study.

The Perameae, a tribe created for the accommodation of the genus Perama Aubl. which originally was included in the Spermacoceae, but which differs from the genera which are left by me in that tribe, by the parallel-nerved leaves, the rudimentary stipules, the insertion of the ovules at the base of the dissepiment and the two-lobed calyx. A two-lobed calyx is found also in Declieuxia H.B.K. and Congdonia Müll.-Arg., two genera which were referred to the Psychotrieae, but which occupy a rather isolated position in that tribe.

The Psychotrieae comprise a large number of genera, even though some of those which by previous authors were included in this tribe, had to be removed to other ones. This applies to the genus Triainolepis Hook. f., which on account of the collateral ovules and the plurilocular pyrene was made the type of a new tribe, the genera Gaertnera Lam. and Pagamea Aubl., which on account of the cylindrical stipular sheath and the almost completely superior ovary, were transferred to a tribe of their own, the Gaertnereae, and the genus Thiersia Baill. (= Evea Aubl.), which, as I could show ("Notes on the Rubiaceae of Surinam" in Rec. d. trav. bot. néerl. $31: 278.1934$ ) is to be included in Faramea Aubl., i.e. in the tribe Coussareae. That the genera Declieuxia H.B.K. and Congdonia occupy a rather isolated position in the Psychotrieae, has already been pointed out. The most characteristic feature of the genera which are left by me in this tribe is the drupe with two or more pyrenes, which differ from those that are usually met with, in the thinness of the sclerenchymatous envelope. That in two of the genera, viz. in Naletonia Brem. and in Notopleura Brem., the valvate aestivation of the corolla lobes is substituted by an imbricate one, has already been mentioned.

The Triainolepideae differ from the Psychotrieae by their collateral ovules and by the presence of a single pyrene which, moreover, is provided with a thick sclerenchymatous envelope; another noteworthy feature are the stipules with their 3,5 or 7 filiform lobes which are crowned by a colleter (see my "Monographie des Triainolepidées, tribu nouvelle des Rubioidées" in Proc. Kon. Ned. Akad. v. Wetensch. Ser. C, 59: 1-21. 1956). The tribe comprises three 
genera, viz. Triainolopis Hook. f., Paratriaina Brem. and Thyridocalyx Brem.

The Lathraeocarpeae agree with the Triainolepideae in the structure of the fruit with its bony plurilocular pyrene, but they differ from them by the presence of but a single ovule in each of the ovary cells and by the pluricolporate instead of tricolporate pollen grains; the stipules, moreover, are united with the base of the sessile leaves and are produced into 1 or 2 stiff points. From the Psychotrieae and most of the other tribes of the Rubioideae they differ in the fleshy instead of horny endosperm (see my paper called "Les Lathraeocarpées, tribu nouvelle des Rubioidées" in Bull. Jard. Bot. de l'État Bruxelles 27: 159-166. 1957). This tribe contains but a single genus, viz. Lathraeocarpa Brem.

The Gaertnereae are an often discussed group which on account of the almost entirely superior ovary seems to occupy a more or less anomalous position in the Rubiaceae, and which on account of this feature was referred by various authors, and at one time by me too, to the Loganiaceae. They are, however, provided with raphides, a form of crystals which is never met with in the true Loganiaceae, and lack the intraxylary phloem which is a characteristic feature of that family. Another point in which they differ from the Loganiaceae in the presence of colletors on the stipules. The almost entirely superior ovary, moreover, is not such an important feature as originally was assumed, because this condition is found also in some of the genera of the Hedyotideae. In most of their characters the Gaertnereae agree with the Psychotrieae; the most important difference, apart from the almost entirely superior ovary, is the union of the stipules into a long cylindrical sheath. The tribe contains but two genera, viz. Gaertnera Lam. and Pagamea Aubl.

The Coussareae come very near to the Psychotrieae, but are easily distinguishable from them by the nature of the dissepiment, which is very thin and which functions for a short time only, and by the presence of a single pyrene with a single seed. This tribe contains but two genera, viz. Coussarca Aubl. and Faramea Aubl.

The Paederieae differ from the Psychotrieae by the greater length of the stigmata and by the dry fruits. In its present delimitation this tribe makes a rather unnatural impression. The genus Aitchisonia Hemsl. is on account of the insertion of the stamens at various heights in the corolla tube and of the presence of glandular hairs certainly to be excluded; it may, as I have pointed out in the second chapter, belong to the Dipsacales, though the combination of glandular hairs and raphides has so far not been found in any of the families included in that order. The other genera doubtless belong to the Rubiaceae, but they differ so strongly from Paederia $\mathrm{L}$ that it seems hardly allowed 
to include them in the same tribe. They belong to the genera which should be studied in more detail.

The Morindeae agree with the Spermacoceae in the way in which the ovules are attached to the dissepiment, but they differ from them in habit and in the nature of the stipules, which though usually united in a sheath, are never provided with filiform appendages; in the genus Didymoecium Brem., probably a near ally of Rennellia Korth., Tribrachya Korth. and Zeuxanthe Ridl., the stipular sheath is produced into intrapetiolar lobes (see my paper on "Didymoecium genus novum Rubiacearum Morindearum" in Bull. Jard. Bot. de Buitenzorg, Ser. 3, 13: 425-428. 1935, where a critical survey is given of the occurrence of intrapetiolar stipules in the Rubiaceae). The genera which were united in this tribe, are on the whole still imperfectly known.

The Knoxieae and the Craterispermeae differ from the other tribes of the Rubioideae with uni- or, rarely, biovular ovary cells in the position of the ovules; the latter are in these two tribes attached to the top of the dissepiment; in the seeds the radicle accordingly points upwards. The Knoxieae (Knoxia L and Pentanisia Harv.) are herbaceous plants, whereas the only genus of the Craterispermeae (Craterispermum Bth.) is shrubby. In the Knoxieae the stipules are usually fringed and in the Craterispermeae entire; the inflorescences, moreover, are in the Knoxieae terminal and in the Craterispermeae axillary.

The eighth subfamily, that of the Hillioideae, comprises but a single tribe, the Hillieae, and this tribe contains in my delimitation but a single genus, viz. Hillia Jacq. Noteworthy features of this genus are the presence of raphides, a character in which it agrees with the genera which are brought together in the Rubioideae, the contorted aestivation of the corolla lobes, a character in which it differs from all of them, and the presence of a tuft of hairs on the top of the seed, a character that is found nowhere else in the Rubiaceae. The wall of the testa cells shows a peculiar structure (see Tab. V a in my work on "The African Species of Oldenlandia"), which reminds one more or less of that found in the genus Gleasonia Standl., but in its other characters Hillia does not show any similarity whatever with this genus.

Among the genera showing a contorted aestivation of the corolla lobes there is one other genus which according to Solereder would contain raphides. This is the genus Deppea Cham. et Schlecht. However, as Solereder in some other instances too mistook styloid crystals for raphides, it is not impossible that this is an error. The genus, therefore, should be reinvestigated.

The survey given in the preceding pages of the results that since the appearance of the last general treatment of the Rubiaceae, viz. that of K. Schumann in Engler and Prantl's "Natürliche Pflanzenfamilien" (1891), have been obtained by the monographic treatment of a 
number of genera and tribes, will have left no doubt with regard to the insufficiency of the older classifications, but it will have shown at the same time that before a fully satisfactory classification can be obtained, a considerable number of genera will have to be reinvestigated. As I am myself unable to continue my work in this field, I must leave this to a younger generation. 